\title{
ENERGY BALANCE SHEET OF A SEMI OPERATIONAL THERMIC SYSTEM
}

\author{
Stanislav Honus ${ }^{* 1,2}$, Veronika Sassmanová ${ }^{2}$, Jaroslav Frantík ${ }^{2}$, \\ Przemyslaw Bukowski ${ }^{2}$ and Dagmar Juchelková ${ }^{1,2}$ \\ ${ }^{1}$ VŠB - Technical University of Ostrava, Faculty of Mechanical Engineering, Department of \\ Energy, 17. listopadu 15/2172, 708 33, Ostrava Poruba, Czech Republic \\ ${ }^{2} \mathrm{VŠB}$ - Technical University of Ostrava, Centre ENET, 17. listopadu 15/2172, 708 33, Ostrava \\ Poruba, Czech Republic
}

\begin{abstract}
The article is focused onthe energetical balance of a technical system for the conversion of crushed tyres by pyrolysis. Process temperatures were set in the range from 500 to $650^{\circ} \mathrm{C}$. Mass input of the material was $30 \mathrm{~kg}$ per hour. The aim of the article is to answer the following questions as regards the individual products: Under which process conditions can the highest quality of the individual products related to energy be reached? How does the thermal efficiency of the system change in reaction to various conditions of the process?
\end{abstract}

On the basis of the experimental measurements and calculations, apart from other things, it was discovered that the pyrolysis liquid reaches the highest energetic value, i.e. $42.7 \mathrm{MJ} . \mathrm{kg}^{-1}$, out of all the individual products of the pyrolysis process. Generated pyrolysis gas disposes of the highest lower calorific value $37.1 \mathrm{MJ}_{\mathrm{kg}}{ }^{-1}$ and the pyrolysis coke disposes of the maximum $30.9 \mathrm{MJ} \mathrm{kg}^{-1}$. From the energetic balance, the thermal efficiency of the experimental unit under the stated operational modes ranging from about $52 \%$ to $56 \%$ has been estimated. Individual findings are elaborated on detail in the article.

Keywords: energy balance, pyrolysis, waste, combustion, process gas

\section{INTRODUCTION}

The worldwide production of caoutchouc continuously increases. The caoutchouc is utilised from $60-70 \%$ for the production of tyres because the number of cars and trucks owners increases, too. The consequence is that there is a worldwide rise of the waste rubber from worn tyres. In 2011, only in Europe about 3 million tons of tyres were produced. Beside automotive industry, for example the mining or aerospace industry presents one of significant sources of worn tyres. (Boroska et al., 2007) A part of the waste tyres is therefore processed in cement-works, another part of them is burnt but most of them are piled up at dumping grounds. From the point of view of the environmental aspects, such as the complicated disposal of tyres, it is necessary to eliminate piling tyres up at dumping grounds and to focus on a suitable method of their recycling in order to utilise the energetic potential of this kind of material. Pyrolysis is an environmentally friendly method and at the same time, it enables to obtain useful products in the power industry e.g. exactly from waste tyres.

Pyrolysis is a process of thermal degradation of the organic material in an inert atmosphere where, by influence of high temperatures, a complicated series of reactions occurs that produces products such as 
the pyrolysis gas, pyrolysis liquid and pyrolysis coke (Conesa et al., 1998; Fronts et al., 2009; Nowacky, 2001; Staf, 2005). In comparison with gasification, no oxygen takes part in the process (Pastor et al., 2008). The gaseous and liquid products obtained from pyrolysis process might be utilised as a source of energy (Crepsi et al., 1999; Guo et al., 2002; Guo et al., 2003). The pyrolysis coke might be utilised as an adsorbent on the base of carbon for adsorption of e.g. acidic compounds created during sewage water treatment (Inguanzo et al., 2002; Zabaitou et al., 2004). Pyrolysis coke could be used as an alternative for metallurgical coke. In form of powder it can be injected through tuyeres into blast furnace aggregate (Jursová et al., 2013).

From a point of view of tyre chemical composition, as opposed to fossil fuels, tyres are relatively homogenous. It is the reason why they were selected for the experimental tests. The article deals with a calculation of energetic balances of the tested pyrolysis system while the tyres were utilised as an input raw material. Some authors were also concerned with the calculation of energetic balance but of the constructionally different systems and different input raw material. Lian and Guomin (2011) made a calculation of the thermal balance of a vacuum pyrolysis system with residual wheat straw used as the input raw material. On the basis of the energetic balances calculation, they concluded that the system selected this way and the selection of input raw material is the best way to carry out energetic regeneration. Savu et al. (2011) created a simplified mathematical model of the thermic system using biomass as a raw material. The model with specially modified software serves to optimise the thermic system and to decrease energetic and material losses on the base of balances calculation. Xiqiang et al. (2011) utilised packs of wheat and corn straw as the input raw material for microwave pyrolysis system (MWP) to find out the total energetic balances of the system. The results demonstrated that the MWP is more advantageous in comparison with conventional systems for example for the retort heating and product distribution. The obtained information on the energetic balances is necessary and useful for design and operation of pyrolysis systems. It is obvious that the energetic balance is the first step to the economic analysis that later designates efficiency and practical utilisation of the tested pyrolysis device (Lian and Guomin, 2011; Quanyuan et al., 2012; Xiqiang et al., 2011).

\section{EXPERIMENTAL SYSTEM DESCRIPTION}

The experimental pyrolysis system specified as PYROMATIC was developed at the VSB - Technical University of Ostrava. The unit is created by a system of partial devices that enable to execute the whole technological process of pyrolysis. That means a transport of the input material to the reactor, its heating up under barred access of air, treatment of the created pyrolysis gas and output of the pyrolysis oil and carbon.

Delivery of the input material is realised by the belt conveyer that feeds it to the hopper from which it is advanced further by means of the screw conveyer to the reactor. The hopper serves as a bin for the input material storage. It can store a maximum of about $120 \mathrm{~kg}$ of crushed tyres. Between the screw conveyer and the reactor, due to thermal dilatations, there is a cloth compensating device (the hopper is attached fixedly, the reactor is moveable).

In the reactor with the active length of $4,000 \mathrm{~mm}$, the material is pyrolysed and at the same time, it is pushed forward by means of the two primary screws and one secondary screw (this one leads the material back to the input part of the retort) with the following diameters of $2 \times 210 \mathrm{~mm}$ and $1 \times 110 \mathrm{~mm}$. The reactor is made of fire-resisting austenitic steel AVESTA 253 MA (EN 1.4835). Its resistivity proves satisfactory up to the temperature of $1100^{\circ} \mathrm{C}$.

During the process, material is heated up and the pyrolysis gas is produced. The gas is drawn off the reactor to the cyclone and further to the coolers where higher hydrocarbons condensate to the pyrolysis 
liquid. Carbonised solid residue is collected in a gas-tight tank located under the device under the edge part of the retort - behind the secondary screw.

The heat for heating the reactor up is supplied by indirect heating from five gaseous burning sections that are placed one after another under the reactor body. Every section is created by the two low pressure atmospheric burners. Maximum thermal input of the furnace is $200 \mathrm{~kW}$, so the maximum is 40 $\mathrm{kW}$ per burner section.

Natural gas is used for reactor heating. Temperatures in the reactor are monitored by thermocouples $\mathrm{K} 11313$ at all the sections and required process temperature is maintained by means of an automatic on-off control. Air for combustion is brought into individual sections through the holes under burners and it can be controlled either by throttling at the input or by revolutions of the exhaust gas fan.

A number of measurement devices ensure control during the operation. All system parameters related to energy are monitored. The unit control is managed from the central control board and all automatically measured quantities are saved to the computer in time intervals and consequently evaluated. The sensors calibration is executed regularly unlike the external devices.

A scheme of the whole system is, including the input and output energy streams, presented in Fig. 1.

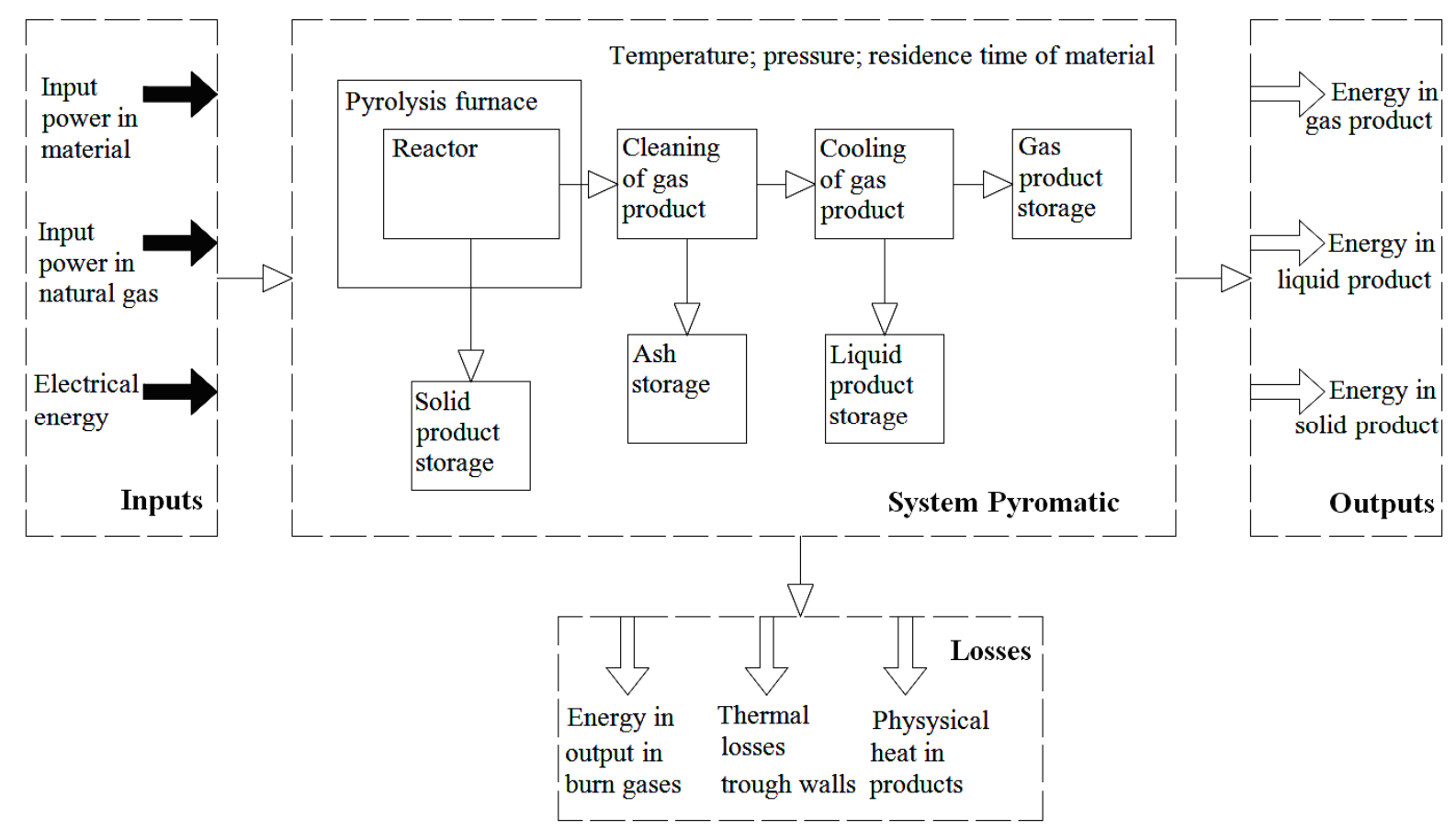

Fig. 1. Streams in experimental system

Within the system, the chemical energy of the natural gas is transformed to burnt gases energy. These gases on the one hand provide thermal input for the material pyrolysis while on the other hand they cover thermal losses (chimney loss and transmission of heat to the surroundings). The input material is by means of the thermal energy of burnt gases converted to gaseous, liquid and solid product. The mechanism of this transformation is constant. However, with a modification of the process conditions (temperature, pressure), the quantity of chemical energy in the individual products (per a unit) changes, too.

Mass input power of the input tyres during the experiments was $30 \mathrm{~kg}$ per hour and the time of the material stay in the reactor was 30 minutes in the primary part and 15 minutes in the secondary part of the reactor. Temperatures from $500{ }^{\circ} \mathrm{C}$ to $650{ }^{\circ} \mathrm{C}$ were selected for the experiments because the gases 
created within the temperature range from $500{ }^{\circ} \mathrm{C}$ to $1200{ }^{\circ} \mathrm{C}$, arestabile. It applies to such gasses as $\mathrm{H}_{2}, \mathrm{CO}, \mathrm{CO}_{2}$ and $\mathrm{CH}_{4}$ which is also stated in the literature (Koppe and Juchelkova, 2011; Staf, 2005; Vymetal and Plesnik, 1994).

Table 1. Tested tyres (rubber) composition

\begin{tabular}{|c|c|c|}
\hline Component & Content & $\begin{array}{c}\text { Method of } \\
\text { Determination }\end{array}$ \\
\cline { 1 - 2 }$C$ & 85.40 & \multirow{2}{*}{ ČSN P ISO TS / } \\
\cline { 1 - 2 }$H$ & 7.57 & \multicolumn{1}{|c}{} \\
\hline$N$ & 0.48 & \\
\hline$S$ & 0.44 & ISO 11722 \\
\hline$O$ & 0.01 & ISO 5071-1 \\
\hline$M$ & 1.71 & ISO 562 \\
\hline$F C$ & 23.03 & ISO 602 \\
\hline$V$ & 70.86 & \\
\hline$A$ & 6.11 & \\
\hline
\end{tabular}

$M$ - Moisture, $F C$ - Fixed Carbon, $V$ - Volatile Combustible, $A$ - Ash

\section{METHODS OF DETERMINATION OF PRODUCTS QUALITY RELATED TO ENERGY}

\subsection{Pyrolysis gas}

During the device operation, composition of the output pyrolysis gas was continuously monitored by analysers that measured concentrations of hydrogen, methane, carbon monoxide, carbon dioxide and of the total organic carbon. Abundance of individual hydrocarbons in the TOC was consequently determined in the laboratory by gas chromatography (Chrom 5) at packed columns MS 5A, Chromosorb 102 and Porapak QS with thermo-conductive (TC) and flame ionised (FI) detection. Samples of gas were sent to the laboratory in gasproof sacks made of nalophan.

Gross calorific value of the pyrolysis gas $Q_{i(g)}$ can be consequently determined from the individual volume fractions by the equation formula:

$$
Q_{i(g)}=\sum_{i=1}^{n} Q_{i, i} \Omega_{i}
$$

where $\Omega_{i}$ is an volumetric fraction of the individual selected (combustible) components in the pyrolysis gas (Leung et al., 2002).

\subsection{Pyrolysis liquid}

Pyrolysis liquid analysis was conducted in the laboratories of DEZA, a.s. Company. The results of the laboratory analysis were measured with the NA 1500 device (made by Fison Instrument Company) for determination of the total content of $\mathrm{C}, \mathrm{H}, \mathrm{N}, \mathrm{O}, \mathrm{S}$. The data were recalculated at the device software according to the Dulong Rule to the net and gross calorific values according to the CSN 656169 standard. 


\subsection{Pyrolysis coke}

Pyrolysis coke analysis was conducted in the analytical laboratories at the VSB - Technical University of Ostrava according to the standardized methodology. The gross and net calorific values as the parameters related to energy for the pyrolysis coke were determined in the laboratory calorimeter according to the CSN EN 15400 Standard - Determination of Net and Gross Calorific Values for Solid Alternative Fuels.

\section{METHOD OF DETERMINATION OF INDIVIDUAL THERMAL FLOWS IN SYSTEM "BURNT GASES ROUTE"}

Total thermal balance comes from the idea that a furnace is a device in which a transformation of the chemically bound energy of the heating gas (released by burning) to the thermal energy of the charge proceeds. A run of this transformation is not absolute because it is connected with a creation of certain energy losses. Thermal balance generally comes from the qualitative and quantitative formulation of the thermal flows entering the furnace and outgoing from it. From the energy conservation law, it can be expressed rigorously:

$$
\dot{Q}_{\text {Input }}=\dot{Q}_{\text {Output }}
$$

where the thermal energy input $\dot{Q}_{\text {Input }}$ is in our case determined by:

$$
\dot{Q}_{\text {Input }}=\dot{Q}_{\mathrm{ChT}, \mathrm{pl}}+\dot{Q}_{\mathrm{FT}, \mathrm{pl}}+\dot{Q}_{\mathrm{FT}, \mathrm{vz}}
$$

and the thermal energy output $\dot{Q}_{\text {Output }}$ is then:

$$
\dot{Q}_{\text {Output }}=\dot{Q}_{R}+\dot{Q}_{\mathrm{K}(\mathrm{ztr})}+\dot{Q}_{\mathrm{Z}(\mathrm{ztr})}+\dot{Q}_{\mathrm{sp}(\mathrm{ztr})}
$$

If we put down the individual energy streams, the equation of the total thermal balance of the pyrolysis furnace will be the following:

$$
\dot{Q}_{\mathrm{ChT}, \mathrm{pl}}+\dot{Q}_{\mathrm{FT}, \mathrm{pl}}+\dot{Q}_{\mathrm{FT}, \mathrm{vz}}=\dot{Q}_{R}+\dot{Q}_{\mathrm{K}(\mathrm{ztr})}+\dot{Q}_{\mathrm{Z(ztr)}}+\dot{Q}_{\mathrm{sp}(\mathrm{ztr})}
$$

\subsection{Heat input}

The burners must supply heat to heat the charge up and to cover thermal losses. Burners' power output/furnace power input $P_{i}$ might be easily determined on the base of the average consumption from the following equation:

$$
P_{i}=\dot{Q}_{C h T, p l}+\dot{Q}_{F T, p l}+\dot{Q}_{F T, v z}=Q_{i, p l} \dot{V}_{p l}+\dot{Q}_{F T, p l}+\dot{Q}_{F T, v z}
$$

Because the temperature of the intake air and temperature of the heating gas are considered the same as the surrounding temperature, these components do not bring any physical heat to the balanced system and the items $\dot{Q}_{\mathrm{FT}, \mathrm{vz}}$ and $\dot{Q}_{\mathrm{FT}, \mathrm{pl}}$ can be ignored in Eq. (6). A simplified equation for the necessary thermal power output of the burners will be

$$
P=\dot{Q}_{C h T, p l}=Q_{i, p l} \dot{V}_{p l}
$$

Every burner of the experimental system is equipped with a gasometer for measuring the amount of the burnt gas. Natural gas consumption in the individual burner sections was automatically read in the 
intervals once per minute. On this basis, the value $\dot{V}_{p l}$ was derived.

\subsection{Thermal losses in outcoming waste burnt gases}

Losses can be divided into two parts. The first one is a loss by the chemical heat of burnt gases that is caused by an imperfect combustion when $\mathrm{CO}$ and $\mathrm{HC}$ are contained in the outcoming burnt gases. In our case, their content is insignificant so this loss can be ignored. The second part is created by a loss caused by the physical heat of the burnt gases. This represents the heat discharged from the furnace in the flue gases. It is the most important loss - it has the greatest impact on the final efficiency. The heat flow in the waste burnt gases $\dot{Q}_{s p(z t r)}$ is dependent on their amount, thermal capacity and temperature (the flue gas average temperatures were: $303{ }^{\circ} \mathrm{C}$, for the process temperature $500^{\circ} \mathrm{C} ; 340^{\circ} \mathrm{C}$ for $550^{\circ} \mathrm{C}$; $356^{\circ} \mathrm{C}$ for $600^{\circ} \mathrm{C} ; 396^{\circ} \mathrm{C}$ for $650^{\circ} \mathrm{C}$ ), respectively.

$$
Q_{\mathrm{sp}(\mathrm{ztr})}=V_{\mathrm{sp}, \mathrm{s}} c_{\mathrm{p}, \mathrm{sp}(\mathrm{odp})} t_{\mathrm{sp}(\mathrm{odp})}
$$

The specific heat of the burnt gases is defined on the basis of known abundance of the components contained in them.

$$
c_{\mathrm{p}, \mathrm{sp}}=c_{\mathrm{p}, \mathrm{CO}_{2}} \omega_{\mathrm{CO}_{2}}+c_{\mathrm{p}, \mathrm{O}_{2}} \omega_{\mathrm{O}_{2}}+c_{\mathrm{p}, \mathrm{N}_{2}} \omega_{\mathrm{N}_{2}}+c_{\mathrm{p}, \mathrm{H}_{2} \mathrm{O}} \omega_{\mathrm{H}_{2} \mathrm{O}}
$$

where $\omega_{i}$ is an volumetric fraction of the given component in the burnt gases that can be derived on the basis of stoichiometry.

Volume flow of burnt gases $\dot{V}_{s p, s}$ was defined on the basis of dynamic and static pressure by means of the Prandtl tube and digital micro manometer. Also a measurement of oxygen concentration in the waste burnt gases with the aim to determine the excess of air during combustion of the heating gas was conducted (for comparison purposes the stoichiometry was taken into consideration for above mentioned concentrations of the individual components in the burnt gases). In both cases the measurement point was in the vertical part of the chimney flue situated behind the burnt gases fan.

The temperature of the burnt gases was automatically recorded at the output from the system - the data were saved to the computer in the intervals lasting one minute as well as in the case of monitoring of the gas consumption

\subsection{Thermal losses by heat transmission to surroundingair by free convection and radiation}

Determination of this component results from the device geometry, characteristics of the insulation cartridges surface and from the measured average surface temperatures. The surface temperatures were measured at all insulation cartridges that create experimental system cover. From the measured data the coefficients of the heat transfer by free convection and radiation might be determined. At first, this combined heat transfer was estimated separately and then the resulting values were summarised. So for the total thermal flow $\dot{Q}_{\mathrm{K}+\mathrm{Z}(\mathrm{ztr})}$ the following equation is valid

$$
\dot{Q}_{\mathrm{K}+\mathrm{Z}(\mathrm{ztr})}=\dot{Q}_{\mathrm{K}(\mathrm{ztr})}+\dot{Q}_{\mathrm{R}(\mathrm{ztr})}
$$

Both thermal flows are specified for every insulation cartridge separately. Apart from many other things, for the precise calculation of the heat transfer to free space it must be considered whether the wall is vertical, horizontal or inclined.

The coefficient of the heat transfer by free convection is derived from the Nusselt number, $N u$ : 


$$
\alpha_{\mathrm{K}(\mathrm{ztr})}=\frac{N u \lambda_{v z}}{L}
$$

The Nusselt number for free convection $N u$ in unlimited space is defined by

$$
N u=c\left(G r P r_{v z}\right)^{n}
$$

where $c, n$ - subsidiary coefficients while it is valid:

- $G r \operatorname{Pr}<1 \cdot 10^{-3} ; \mathrm{c}=0.45 ; \mathrm{n}=0$

- $1 \times 10^{-3} \leq G r \operatorname{Pr}<5 \cdot 10^{2} ; \mathrm{c}=1.18 ; \mathrm{n}=0.125$

- $5 \cdot 10^{2} \leq G r \operatorname{Pr}<2 \cdot 10^{7} ; \mathrm{c}=0.54 ; \mathrm{n}=0.25$

- $2 \cdot 10^{7} \leq G r \operatorname{Pr} ; \mathrm{c}=0.135 ; \mathrm{n}=1 / 3$

In the case of horizontal plates inverted by a warm side up, the coefficient $c$ is increased by $30 \%$, while at horizontal plates inverted by a warm side down the coefficient $c$ is decreased by $30 \%$. In the case of the inclined plates, $c$ is increased by $15 \%$.

The Grashof number $G r$ which is a part of Eq. (12) is defined:

$$
G r=\frac{g L^{3}}{v_{v z}^{2}} \frac{1}{\frac{T+T_{o k}}{2}} \Delta t
$$

Total thermal loss by free convection is simply defined as

$$
\dot{Q}_{\mathrm{K}(\mathrm{ztr})}=\alpha_{\mathrm{K}(\mathrm{ztr})}\left(t_{S}-t_{o k}\right) \sum S_{i}
$$

The total radiation flow emitted by walls of the unit to the space of the hall is defined by the relation:

$$
\dot{Q}_{\mathrm{Z}(\mathrm{ztr})}=\varepsilon_{S H} C_{0}\left[\left(\frac{T_{S}}{100}\right)^{4}-\left(\frac{T_{H}}{100}\right)^{4}\right] \sum S_{i}
$$

where $C_{0}$ is radiation constant $\left(5.67\left[\mathrm{~W} \cdot \mathrm{m}^{-2} \cdot \mathrm{K}^{-4}\right]\right), T_{H}$ thermodynamic temperature of the hall walls (293.15 [K]) and $\varepsilon_{S H}$ a degree of the system emissivity (system in the hall space):

$$
\varepsilon_{S H}=\frac{1}{\frac{1}{\varepsilon_{P 2}}+\frac{S_{i}}{S_{H}}\left(\frac{1}{\varepsilon_{H}}-1\right)}
$$

\section{RESULTS AND DISCUSSION}

During the pyrolysis process usually $24-30 \mathrm{wt} \%$ of the pyrolysis gas, $33-40 \mathrm{wt} \%$ of the pyrolysis liquid and $31-41 \mathrm{wt} \%$ of the pyrolysis coke were created which was demonstrated with regard to process temperature selection and also on the basis of our experiments (Helleur et al., 2001; Xiqiang et al., 2011).

It was discovered that from 15 to $31 \%$ of pyrolysis gas volume consists of carbon monoxide and hydrogen in various proportions depending on the selected temperature of the pyrolysis process. With the temperature rise the hydrogen proportion in the gas increases significantly and the carbon dioxide proportion decreases slightly. 
Table 2. Mass abundance of pyrolysis products depending on process temperature

\begin{tabular}{|c|c|c|c|c|}
\hline Process temperature $\left[{ }^{\circ} \mathrm{C}\right]$ & 500 & 550 & 600 & 650 \\
\hline Mass abundance of pyrolysis gas [\%] & 30.1 & 24.1 & 26.5 & 26.5 \\
\hline Mass abundance of pyrolysis coke [\%] & 31.3 & 36.1 & 41.0 & 41.0 \\
\hline Mass abundance of pyrolysis liquid [\%] & 38.6 & 39.8 & 32.5 & 32.5 \\
\hline
\end{tabular}

The majority component of the pyrolysis gas is mostly a sum of hydrocarbons in which methane has the highest abundance. The ratio of hydrocarbons in the gas ranges from $33 \%$ to $51 \%$ with the average value of $41 \%$. The production of hydrocarbons in the pyrolysis gas in all cases increases up to the process temperature of $600^{\circ} \mathrm{C}$. At a higher temperature of $650^{\circ} \mathrm{C}$ the hydrocarbons content is already lower because the increase of the temperature decreases their abundance in a fixed condition.

Table 3 represents the average measured concentrations of the selected components in the pyrolysis gas from pyrolysis of waste tyres and at various process temperatures. The rest (which balance the gas volume to $100 \%$ ) are gases called "ballast", like $\mathrm{N}_{2}, \mathrm{SO}_{2}$, or $\mathrm{H}_{2} \mathrm{~S}$. They were not measured because they do not influence the calorific value.

Table 3. Concentration of selected components in pyrolysis gas with regard to the process temperature

\begin{tabular}{|c|c|c|c|c|c|c|c|c|c|c|}
\hline \multirow{2}{*}{$\begin{array}{c}\text { Process } \\
\text { Temperature }\end{array}$} & \multicolumn{10}{|c|}{ Sample Designation } \\
\hline & $\mathrm{H}_{2}$ & $\mathrm{CO}$ & $\mathrm{CO}_{2}$ & $\mathrm{CH}_{4}$ & $\mathrm{C}_{2} \mathrm{H}_{4}$ & $\mathrm{C}_{2} \mathrm{H}_{6}$ & $\sum \mathrm{C}_{3} \mathrm{H}_{\mathrm{Y}}$ & $\sum \mathrm{C}_{4} \mathrm{H}_{\mathrm{Y}}$ & $\sum \mathrm{C}_{5} \mathrm{H}_{\mathrm{Y}}$ & $\sum \mathrm{C}_{6} \mathrm{H}_{\mathrm{Y}}$ \\
\hline$\left[{ }^{\circ} \mathrm{C}\right]$ & \multicolumn{10}{|c|}{$[\%]$} \\
\hline 500 & 12.4 & 2.8 & 2.4 & 17.9 & 3.0 & 4.4 & 5.6 & 4.2 & 4.5 & 0.8 \\
\hline 550 & 13.3 & 3.7 & 2.3 & 19.8 & 3.9 & 4.7 & 5.2 & 3.6 & 2.4 & 1.0 \\
\hline 600 & 22.2 & 3.1 & 1.9 & 29.2 & 4.0 & 4.9 & 5.4 & 3.7 & 2.5 & 1.1 \\
\hline 650 & 28.3 & 2.9 & 1.4 & 4.6 & 5.2 & 6.3 & 7.0 & 4.8 & 3.2 & 1.4 \\
\hline
\end{tabular}

An interesting problem is $\mathrm{CH}_{4}$ production in different temperatures. According to the Francis diagram and numerical calculation the methane content should decrease with the rise of temperature. In our measurements the $\mathrm{CH}_{4}$ content is the highest for $600^{\circ} \mathrm{C}$. We explain it as the influence of tyre fragmentation, which influences its reactivity afterwards. But this dependence needs a further investigation, and measurements at different fragmentation.

As it follows from Table 2 with increasing temperature of the pyrolysis process, the volume of the formed gaseous products increases at the expense of solid and liquid products. From the point of view of the process temperature, it is valid that the pyrolysis gas generated at temperature of $600^{\circ} \mathrm{C}$ has the

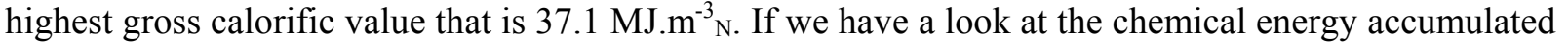
in the gas related to its concrete produced volume, then with the increasing temperature, the energy stream always increases.

The pyrolysis liquid shows the highest value of the gross caloric value when it is formed at the process temperature of $500^{\circ} \mathrm{C}$. It is valid that with the increasing process temperature, the gross calorific value of the created pyrolysis liquid decreases. Among the individual products of pyrolysis, the pyrolysis liquid reveals the highest quality related to energy (up to $42.7 \mathrm{MJ} \cdot \mathrm{kg}^{-1}$ ).

The calorific value of the pyrolysis coke is the lowest in comparison with the other products of the pyrolysis - it is on average of about $30.3 \mathrm{MJ} \cdot \mathrm{kg}^{-1}$ (we took the average from 4 measurements at temperatures from $500{ }^{\circ} \mathrm{C}$ to $650{ }^{\circ} \mathrm{C}$ ). The same value of the pyrolysis gas is on average $34.3 \mathrm{MJ} \cdot \mathrm{kg}^{-1}$ and for the pyrolysis liquid it is $40.6 \mathrm{MJ} \cdot \mathrm{kg}^{-1}$. With the process temperature the gross calorific value of 
the pyrolysis coke increases as well as the energy stream increases when related to the produced volume of the pyrolysis coke (the influence of fuel temperature on the calorific value was omitted).

The calorific value of the pyrolysis coke is the lowest in comparison with the other products of the

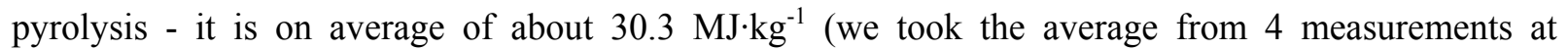
temperatures from $500{ }^{\circ} \mathrm{C}$ to $650{ }^{\circ} \mathrm{C}$ ). The same value of the pyrolysis gas is on average $34.3 \mathrm{MJ} \cdot \mathrm{kg}^{-1}$ and for the pyrolysis liquid it is $40.6 \mathrm{MJ} \cdot \mathrm{kg}^{-1}$. With the process temperature the gross calorific value of the pyrolysis coke increases as well as the energy stream increases when related to the produced volume of the pyrolysis coke (the influence of fuel temperature on the calorific value was omitted).

Of course, also the stream of heating gas, volume stream of burnt gases increase with increasing temperature of pyrolysis. Understandably, consumption of electrical energy per 30 minutes of the operation under a constant input power differs minimally at all the temperatures.

The pyrolysis process generates losses. It causes all energy streams to diminish, even the chemical ones (see Fig. 2). The chemical energy, calculated as a low calorific value multiplied by the input or output material mass stream, was diminishing in the pyrolysis reactor. Thermal losses (as flue gases loss) and the nature of the pyrolysis process are the reasons of endothermic reaction appearance.

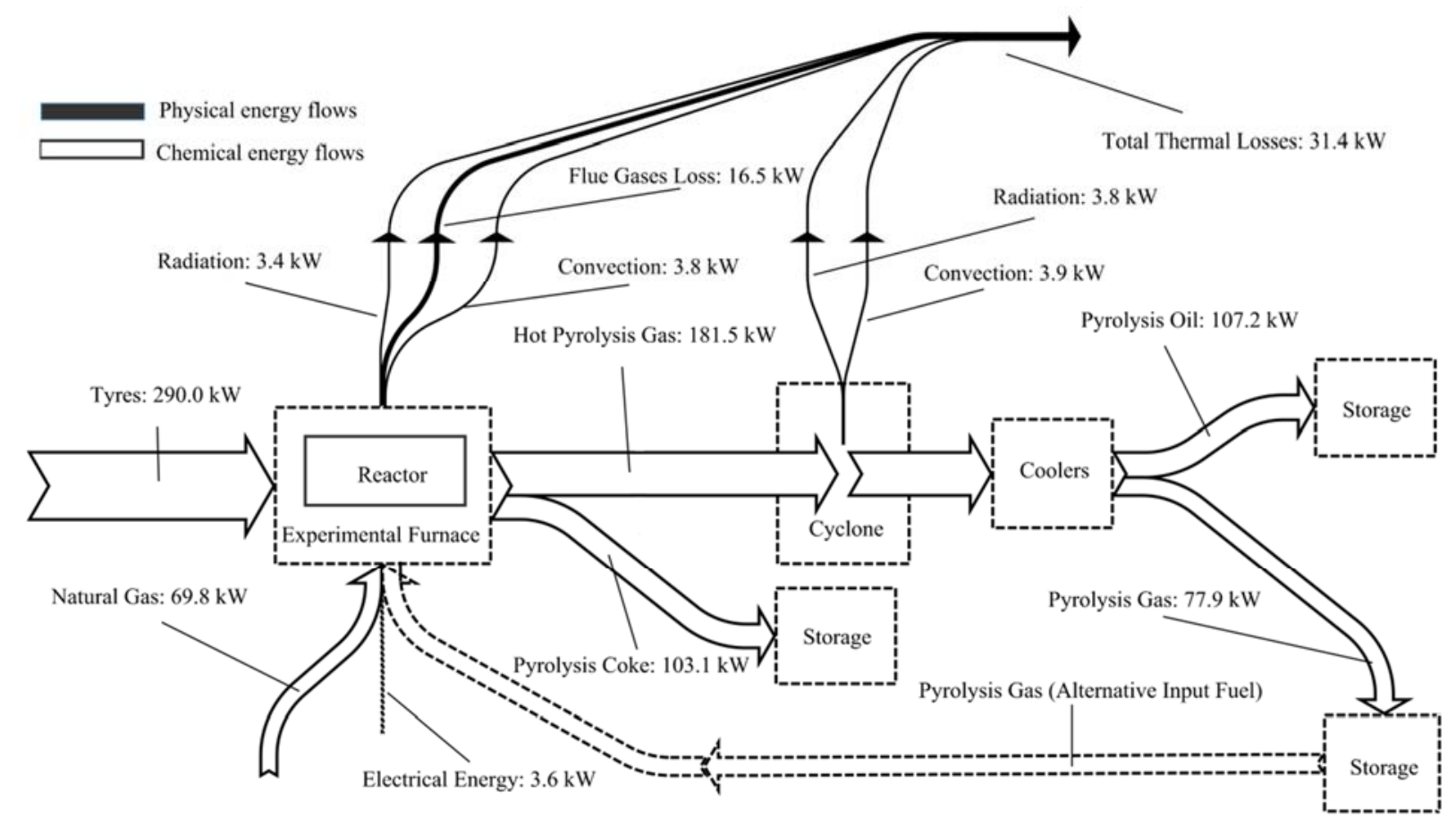

Fig. 2. Energy streams; examined input material: tyres, temperature: $600^{\circ} \mathrm{C}$

Thermal losses increase with the increasing temperature (which is obvious) but the total thermal efficiency of the examined pyrolysis device was not always the highest for the lowest temperatures.

Typical thermal energy streams for waste tyres are also presented in Fig. 2. The greatest thermal energy loss is a "chimney loss" (the wasted heat in flue gases) but this loss can be diminished by heat recuperation. That is why it can be said, that the pyrolysis device efficiency could be higher.

On the basis of the measured heat losses and the input gas chemical energy, the total thermal efficiency of the unit was calculated (see the last row in Table 4). The thermal efficiency did not increase as expected. The highest efficiency (close to $55 \%$ ) was calculated for the temperature range between 550 and $600{ }^{\circ} \mathrm{C}$. 
Table 4. Inputs and outputs of mass and energies

\begin{tabular}{|c|c|c|c|c|c|c|c|}
\hline & \multirow{2}{*}{\multicolumn{4}{|c|}{ Process temperature $\left[{ }^{\circ} \mathrm{C}\right]$}} \\
\hline & & & & & & & \\
\hline \multicolumn{3}{|c|}{ Name } & Unit & 500 & 550 & 600 & 650 \\
\hline \multirow{4}{*}{$\begin{array}{l}\text { Average quality } \\
\text { of pyrolysis } \\
\text { products related } \\
\text { to energy }\end{array}$} & Net Calorific Value & Gas & {$\left[\mathrm{kJ} \cdot \mathrm{m}^{-3} \mathrm{~N}\right]$} & 31136 & 28749 & 33846 & 31790 \\
\hline & \multirow{3}{*}{$\begin{array}{c}\text { Lower Calorific } \\
\text { Value }\end{array}$} & Gas & {$\left[\mathrm{kJ} \cdot \mathrm{m}^{-3} \mathrm{~N}\right]$} & 33944 & 31380 & 37089 & 34679 \\
\hline & & Semicoke & {$\left[\mathrm{kJ} \cdot \mathrm{kg}^{-1}\right]$} & 29718 & 30420 & 30319 & 30906 \\
\hline & & Oil & {$\left[\mathrm{kJ} \cdot \mathrm{kg}^{-1}\right]$} & 45696 & 41787 & 39689 & 38331 \\
\hline \multirow{2}{*}{$\begin{array}{l}\text { INPUTS of } \\
\text { mass/volume }\end{array}$} & \multicolumn{2}{|c|}{ Material mass stream } & {$\left[\mathrm{kg} \cdot \mathrm{s}^{-1}\right]$} & 0.0083 & 0.0083 & 0.0083 & 0.0083 \\
\hline & \multicolumn{2}{|c|}{ Natural Gas stream } & {$\left[\mathrm{m}^{3} \mathrm{~N} \cdot \mathrm{s}^{-1}\right]$} & 0.0432 & 0.0669 & 0.0814 & 0.1004 \\
\hline \multirow{2}{*}{ Energy INPUTS } & \multicolumn{2}{|c|}{ El. energy $(30 \mathrm{~min})(3.1-3.11)$} & {$[\mathrm{kWh}]$} & 1.37 & 1.72 & 1.82 & 1.93 \\
\hline & \multicolumn{2}{|c|}{ Input power in natural gas $(1.2-1.6)$} & {$[\mathrm{kW}]$} & 40.20 & 58.27 & 69.75 & 79.69 \\
\hline \multirow{4}{*}{$\begin{array}{l}\text { OUTPUTS of } \\
\text { mass/volume }\end{array}$} & \multicolumn{2}{|c|}{ Volume stream of waste burnt gases } & {$\left[\mathrm{m}^{3} \mathrm{~N}^{\left.-\mathrm{s}^{-1}\right]}\right.$} & 0.0284 & 0.0412 & 0.0495 & 0.0566 \\
\hline & \multicolumn{2}{|c|}{ Volume stream of pyrolysis gas } & {$\left[\mathrm{m}^{3} \mathrm{~N}^{-1}\right]$} & 0.0018 & 0.0023 & 0.0021 & 0.0028 \\
\hline & \multicolumn{2}{|c|}{ Mass stream of semicoke } & {$\left[\mathrm{kg} \cdot \mathrm{s}^{-1}\right]$} & 0.0026 & 0.0030 & 0.0034 & 0.0034 \\
\hline & \multicolumn{2}{|c|}{ Mass stream of pyrolysis oil } & {$\left[\mathrm{kg} \cdot \mathrm{s}^{-1}\right]$} & 0.0032 & 0.0033 & 0.0027 & 0.0027 \\
\hline \multirow{10}{*}{$\begin{array}{l}\text { Energy } \\
\text { OUTPUT }\end{array}$} & \multicolumn{2}{|c|}{ Energy in output burnt gases } & {$[\mathrm{kW}]$} & 7.99 & 13.20 & 16.47 & 21.45 \\
\hline & \multicolumn{2}{|c|}{$\mathrm{T}^{*}$ power input in pyrolysis gas $(\mathrm{NCV})$} & {$[\mathrm{kW}]$} & 55.76 & 64.94 & 69.62 & 88.72 \\
\hline & \multicolumn{2}{|c|}{$\mathrm{T}^{*}$ power input in pyrolysis gas $(\mathrm{GCV})$} & {$[\mathrm{kW}]$} & 61.10 & 72.17 & 77.89 & 97.10 \\
\hline & \multicolumn{2}{|c|}{$\mathrm{T} .^{*}$ power input in pyrolysis coke (GCV) } & {$[\mathrm{kW}]$} & 77.27 & 91.26 & 103.08 & 105.08 \\
\hline & \multicolumn{2}{|c|}{ T. ${ }^{*}$ power input in pyrolysis oil (GCV) } & {$[\mathrm{kW}]$} & 146.23 & 137.90 & 107.16 & 103.49 \\
\hline & \multicolumn{2}{|c|}{ Losses by radiation-furnace } & {$[\mathrm{kW}]$} & 2.37 & 2.84 & 3.37 & 3.84 \\
\hline & \multicolumn{2}{|c|}{ Losses by convection-furnace } & {$[\mathrm{kW}]$} & 2.67 & 3.21 & 3.83 & 4.35 \\
\hline & \multicolumn{2}{|c|}{ Losses by radiation-cyclone } & {$[\mathrm{kW}]$} & 2.70 & 3.24 & 3.83 & 4.47 \\
\hline & \multicolumn{2}{|c|}{ Losses by convection-cyclone } & {$[\mathrm{kW}]$} & 2.95 & 3.44 & 3.93 & 4.44 \\
\hline & \multicolumn{2}{|c|}{ Total thermal losses through walls } & {$[\mathrm{kW}]$} & 10.70 & 12.73 & 14.96 & 17.09 \\
\hline \multicolumn{3}{|c|}{ System thermal efficiency } & {$[\%]$} & 53.5 & 55.5 & 54.9 & 51.6 \\
\hline
\end{tabular}

*”T. power input" stands for "thermal power input"

\section{CONCLUSIONS}

The research conducted on the Semioperational pyrolysis system PYROMATIC confirmed that pyrolysis is a highly effective way of the tyre utilisation. On the basis of the measured values and calculated data, it was found that the process conditions might be set according to the parameters of quantity or quality that are the most important for the end user.

The highest thermal efficiency of the system was estimated at the process temperature of $550{ }^{\circ} \mathrm{C}$ while at other temperatures the divergence from that efficiency value is not considerable. The pyrolysis gas has the highest gross calorific value if it is produced at the process temperature of $600^{\circ} \mathrm{C}$. On the basis 
of the investigated quality and quantity of the pyrolysis gas it can be stated that it is suitable to be used as reactor heating gas and by that the absolute process self-sufficiency might technically be realised. The pyrolysis liquid has the best quality related to energy from all the individual products and in order to obtain the liquid of the top quality related to energy, it is necessary to select the process temperature at $500{ }^{\circ} \mathrm{C}$. As regards the pyrolysis coke, it has the lowest gross calorific value from all the pyrolysis products. It is valid further that the process temperature, at which it was produced, has little influence on its quality related to energy.

The article was written under support of the following projects: CZ.1.07/2.3.00/30.0016 - Opportunity for young researchers, CZ.1.05/2.1.00/03.0069 - VaVpI OP2 výzva 2 ENET and CZ.1.07/2.3.00/30.0055 - New creative teams in priorities of scientific research.

\section{SYMBOLS}

$\begin{array}{ll}C_{0} & \text { radiation constant, } \mathrm{W} \cdot \mathrm{m}^{-2} \cdot \mathrm{K}^{-4} \\ G r & \text { Grashof number, - } \\ L & \text { characteristic dimension, } \mathrm{m} \\ N u & \text { Nusselt number, - } \\ P_{i} & \text { Burners' power output/furnace power input, } \mathrm{kW} \\ \mathrm{Pr} & \text { Prandtl number, - } \\ \dot{V}_{p l} & \text { volume inflow of the heating gas, } \mathrm{m}^{3}{ }_{\mathrm{N}} \cdot \mathrm{s}^{-1} \\ \dot{V}_{s p, s} & \text { volume flow of burnt gases, } \mathrm{m}^{3}{ }_{\mathrm{N}} \cdot \mathrm{s}^{-1} \\ Q_{i(g)} & \text { gross calorific value of the pyrolysis gas, } \mathrm{kJ} \cdot \mathrm{m}^{-3} \mathrm{~N} \\ Q_{\mathrm{i}, \mathrm{pl}} & \text { net calorific value of the heating gas, } \mathrm{kJ} \cdot \mathrm{m}^{-3} \mathrm{~N} \\ \dot{Q}_{\mathrm{ChT}, \mathrm{pl}} & \text { chemical heat in the heating gas (flow), } \mathrm{kW} \\ \dot{Q}_{\mathrm{FT}, \mathrm{pl}} & \text { physical heat in the heating gas (flow), } \mathrm{kW} \\ \dot{Q}_{\mathrm{Input}} & \text { input energy flow, } \mathrm{kW} \\ \dot{Q}_{\mathrm{FT}, \mathrm{vz}} & \text { physical heat in the combustion air (flow), } \mathrm{kW} \\ \dot{Q}_{\mathrm{FT}, \mathrm{pl}} & \text { physical heat in the heating gas (flow), } \mathrm{kW} \\ \dot{Q}_{\mathrm{K}(\mathrm{ztr})} & \text { total thermal loss by free convection, } \mathrm{kW} \\ \dot{Q}_{\mathrm{K}+\mathrm{Z}(\mathrm{ztr})} & \text { thermal losses (free convection }+ \text { radiation), } \mathrm{kW} \\ \dot{Q}_{\mathrm{Output}} & \text { output energy flow, } \mathrm{kW} \\ \dot{Q}_{R} & \text { thermal flow to reactor walls (necessary to the charge heating up), } \mathrm{kW} \\ \dot{Q}_{\mathrm{R}(\mathrm{ztr})} & \text { total thermal loss by radiation, } \mathrm{kW} \\ \dot{Q}_{\mathrm{Sp}(\mathrm{ztr})} & \text { thermal flow in waste burnt gases, } \mathrm{kW} \\ \dot{Q}_{\mathrm{Z}(\mathrm{ztr})} & \text { thermal losses by heat transmission (a component of radiation), } \mathrm{kW} \\ S_{H} & \text { surface of the walls in the hall where the pyrolysis system is placed, } \mathrm{m}^{2} \\ S_{i} & \text { area of the given insulation cartridge, } \mathrm{m}^{2} \\ T_{H} & \text { thermodynamic temperature of the hall walls, } \mathrm{K} \\ T_{o k} & \text { thermodynamic temperature of the surrounding, } \mathrm{K} \\ c & \text { subsidiary coefficient, - } \\ & \end{array}$




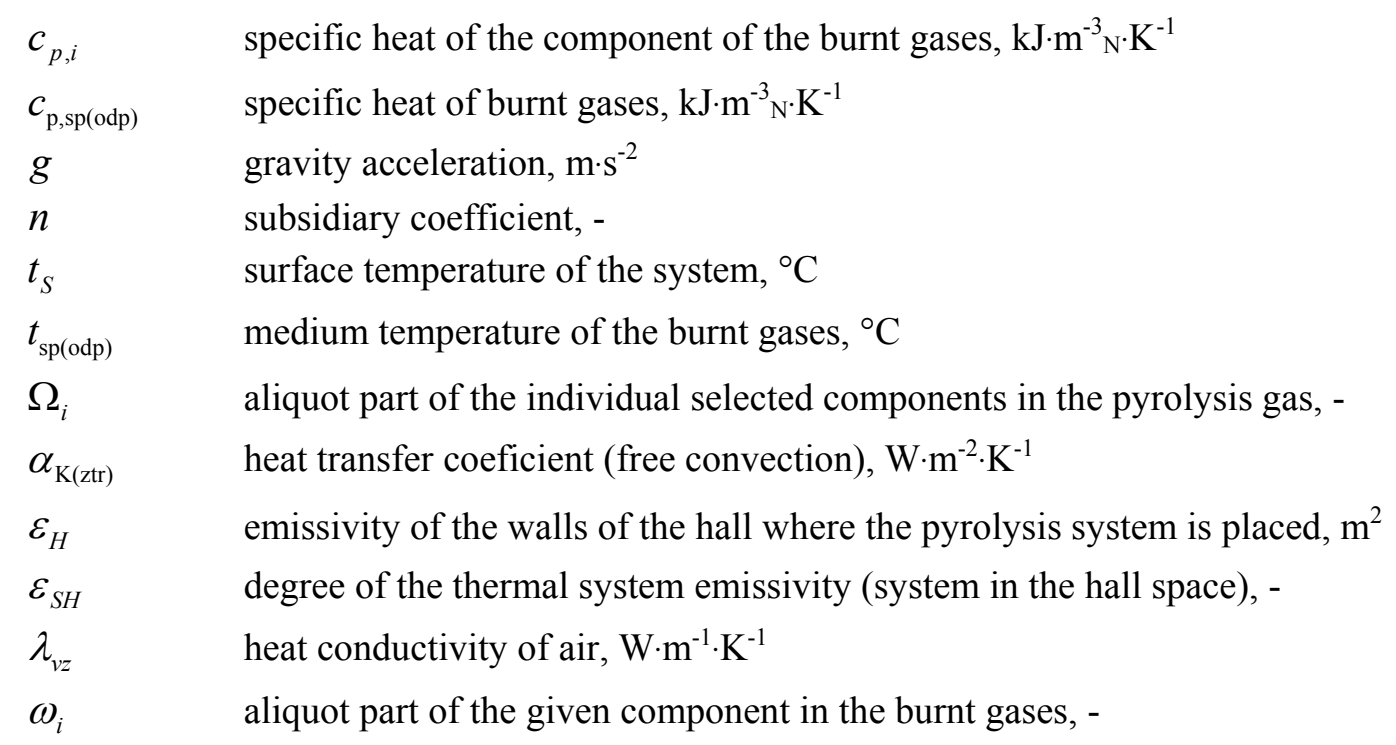

\section{REFERENCES}

Boroska J., Molnar V., Fedorko G., Husakova N., 2007. Mining optimization indepence on the capacity of transport, In: Modern trends in underground construction. 163 - 167. Rudarsko-geolološki fakultet Univerziteta Beograd.

Conesa J.A., Marcilla A., Moral R., Moreno-Casselles J., Perez-Espinosa A., 1998. Evolution of gases in primary pyrolysis of different sewage sludge. Termochimica Acta, 313, 63-73. DOI: 10.1016/S0040-6031(97)00474-7.

Crespi M.S., Ribeiro C.A., Greenhalf V.C.M., Zorel J.R.H.M., 1999. Preparation and thermal decomposition of copper(II), zinc(II) and cadmium(II) chelates with 8-hydroxyquinoline. Quím. Nova, 22 (1). DOI: 10.1590/S0100-40421999000100009.

Fronts I., Azuara M., Gea G., Murillo M.B., 2009. Study of pyrolysis liquids obtained from different sewage sludge. J. Anal. Appl. Pyrolysis, 85, 184-191. DOI: 10.1016/j.jaap.2008.11.003.

Guo R., Yang J., Liu D., Liu Z., 2002. Transformation behaviour of trace elements during coal pyrolysis. Fuel Process. Technol., 77-78, 137-143. DOI: $10.1016 / \mathrm{S} 0378-3820(02) 00041-3$.

Guo R., Yang J., Liu D., Liu Z., 2003. The fate of As, Pb, Cd, Cr and Mn in a coal during pyrolysis. J. Anal. Appl. Pyrolysis, 70, 555-562. DOI: 10.1016/S0165-2370(03)00025-1.

Helleur R., Popovic N., Ikura M., Stanciulescu M., Liu D., 2001. Characterization and potential applications of pyrolytic char from ablative pyrolysis of used tires. J. Anal. Appl. Pyrolysis, 58-59, 813-824. DOI: 10.1016/S0165-2370(00)00207-2.

Inguanzo M., Domingguez A., Mendez J.A., Blanco C.G., Pis J.J., 2002. On the pyrolysis of sewage sludge: The influence of pyrolysis conditions on solid, liquid and gas fractions. J. Anal. Appl. Pyrolysis, 63, 209-222. DOI: 10.1016/S0165-2370(01)00155-3.

Jursová S., Pustějovská P., Brozova S., 2013. Energy exploitation of industrial waste. 22nd International Conference on Metallurgy and Materials, 15 - 17 May 2013, Brno, Czech Republic.

Koppe K., Juchelková D., 2011. Bioenergi - Handbuch. Ostrava.

Leung, D. Y. C., Yin X. L., Zhao Z. L., Xu B. Y., Chen, Y., 2002. Pyrolysis of tire powder: Influence of operation variables on the composition and yields of gaseous product. Fuel Process. Technol., 79, 141-155. DOI: 10.1016/S0378-3820(02)00109-1.

Lian Wang and Guomin Xiao, 2011. Study on economic feasibility of straw pyrolysis. International Conference on Materials for Renewable Energy \& Environment (ICMREE). Shanghai, China, 20 - 22 May 2011.

Nowacky P., 1981. Coal gasification processes. Noyes Data Corporation/Noyes Publications, New Jersey.

Pastor M., Budayova M., Varga A., Suchy T., Fedorko G., Analysis of alternativ fuel - biomass gasifying at fluid reactor. 2nd International Symposium Meaning Energetic. Rudarsko-geolološki fakultet Univerziteta Beograd.

Quanyuan W., Yongshui Q., Tianwei, T., 2012. Mass and heat balance calculations and economic evaluation of an innovative biomass pyrolysis project. Front. Chem. Sci. Eng., 5, 355-361. DOI: 10.1007/s11705-010-0567-9. 
Savu A., R., Muntean I., Lazea G., Agachi P., S., 2011. Economic optimization of a thermal cracker via Model Predictive Control technology. 19th Mediterranean Conference on Control and Automation Aquis. Corfu Holiday Palace, Corfu, Greece June 20-23, 2011.

Staf M., 2005. Research of thermic conversion of waste biomass to gaseous and liquid fuels, available at: $\mathrm{http} / /$ biom.cz/cz/odborne-clanky/vyzkum-termicke-konverze-odpadni-biomasy-na-plynna-a-kapalna-paliva (in Czech).

Vymětal J., Plesník M., 1994. Black coal tar and natural resin processing study manual. I. DEZA a.s. Valašské Meziřríčí.

Xiqiang Zhao, Jian Zhang, Zhanlon Song, Hongzhen Liu, Longzhi Li, Chunyuan M., 2011. Microwave pyrolysis of straw bale and energy balance analysis. J. Anal. Appl. Pyrolysis, 92, 43 - 49. DOI: 10.1016/j.jaap.2011.04.004.

Received 21 May 2013

Received in revised form 19 March 2014

Accepted 30 April 2014 